\title{
Hamlet or Ahab, Who Is Great?
}

\author{
WANG Wei \\ Quzhou University, Quzhou,China
}

\begin{abstract}
Hamlet and Ahab are tragedy heroes of two great writers - Shakespeare and Melville. Revenge is the most important clue in each play. This paper analyses the greatness of them through the comparison between the two heroes of the two revengeful tragedies in several aspects, such as their characters, the differences and similarities of their revenge, fighting against society and nature, achievements, social morality, and so on.
\end{abstract}

Keywords: Hamlet, Ahab, character, revengeful tragedy, nature

\section{Introduction}

Hamlet and Moby Dick are tragedies belonging to two different ages; the former is a division of Elizabethan tragedy while the latter is of modern American tragedy. Shakespeare is one of the greatest playwrights in literature world. "To be sure, Melville's Shakespearing shapes some of the deepest moments in Moby Dick" (WANG, 1997). The creativity of Moby Dick is deeply affected by Shakespeare's work .The two works have some similarities that a tragedy has, at the same time, pose differences due to their different ages. A comparison and contrast will be presented here to show the similarities and differences between the two tragedies concerning such aspects: the character of the two heroes-Hamlet and Ahab, the similarities and differences of revenge; it also compares their social morality, fighting against society and nature, achievements, and so on.

The main characters in these two plays are quite different in family background: Hamlet, the prince of Denmark, the tragic hero of Hamlet, is a noble man of high birth, whereas Ahab, the tragic hero of Moby Dick, is only an ordinary man as he is a captain of Pequod. The two heroes also have some similarities in their reason, process of revenge, etc., they both have their own advantages, who is great? Different people may hold different attitudes toward this issue.

\section{Comparison of Character Between Hamlet and Ahab}

\section{Hamlet-Hesitation}

Hamlet represents the type of man whose power of direct action is paralyzed by an excessive development of his intellect. The 19th century English poet and critic Coleidge, himself an intellectual, who felt that thinking and imaging had made him impractical, suggested that Hamlet also thought too much and so do too little, in the process of revenge. Hamlet is in deep depression, but it is natural for anyone else in his shoes - with father and mother stained. His character changes "I have of late, but wherefore I know not, lost all my birth, forgone all custom of exercises". Hesitation is also his fatal flaw in taking revenge for his father, "It is hardly understandable that he did not take action after this" (WANG, 1997). Although Hamlet is responsible for his

WANG Wei, lecturer, master, College of Foreign Languages, Quzhou University. 
downfall as it is his own "hamritia", which leads him to a fall, he still deserves sympathy because he realizes his procrastination and gets his revenge before his death. The character of hesitation hinders him from revenging at good chance, and this also causes even more innocent death at the end of the play.

\begin{abstract}
Ahab-Bravery
Ahab has the opposite character to Hamlet, as the hero of the Moby Dick, he is the dominator of the Pequod, "To Ahab, Moby Dick is definitely evil, He shows great hatred to Moby Dick" (ZHAO, 1999). Nothing can stop him, with the appearance of revenge. Ahab regards Moby Dick as evil of everything and fights against him to the last breathe. The desire and will of revenge appear as a frighten strength which makes Ahab revenge at any prices, when he meets the captain of the Samuel Enderby, it is clear that his only interest is "What happened to the White Whale?" (Melville, 2004). The only task for the old captain is to kill Moby Dick, he knows that his purpose is adventurous and dangerous; he does not give up and does not want to be failure before an animal, before nature. At the very chase and search of Moby Dick, the captain's desire comes to its summit, and his life is extremely satisfied. From the first time of whaling in 18 to die with the white whale in 58, Ahab spends his 40 years life on the sea, it is a long period for anyone else; it is a process of winning and passing; it is also a process of enjoying freedom; it is sprite of superman; he is a brave man, therefore, bravery is Ahab's central character; it is fully showed during the process of chasing the white whale.
\end{abstract}

\title{
From Comparison and Analysis of Hamlet and Ahab's Revenge, Who Is Great?
}

\section{Differences of Reason of Revenge}

Hamlet, as the prince of Denmark, is a noble man of high birth, and he has access to good education and is good at so many things, and we can see that he should ascend the throne, but he comes across misfortune, the old Hamlet, namely the old king suddenly dies, the new king who does away with his father, and takes father's place with his mother, and the man who is his father's brother, he is Claudius, the present king; especially after hearing the ghost's words "Thus was I, sleeping, by a brother's hand, of life, of crown, of queen, at once dispatch'd". All the changes trouble the young prince, Hamlet, as is known, there is an old saying in China: Blood is always thicker than water, according to the Chinese version, anyone who kills his family members will be considered immoral and should be severely punished by the heaven.

The task of revenge is always in his heart; it is not only a son's duty but also a prince's duty, and he must do like this which is also Hamlet's responsibility to revenge. Can he give the country a satisfied answer? Hamlet thinks "The time is out of joint. O cursed spite, that ever I was born to see it right", "Claudius is a murderer and usurper". To kill him is a sacred duty to the nation, to the community, to justice, to the old king, to Hamlet himself, even to heaven.

Ahab, compared with Hamlet, is only a captain of Pequod. As the tragic hero of Moby Dick, he is only an ordinary man of common birth as he is only a common sailor; he does not receive good education. He is the representative of whaling people of 18th century of American; whaling is their main source of life. When they go to the sea from land to whale, they get into another society where they can relax themselves, and enjoy the interest of whaling. Ahab is no exception. White the whale-Moby Dick, to Ahab, is the evil. He shows great hatred to the monster, because the monster has grabbed one of the captain's legs. "Just at that moment, Moby Dick stuck out his curved lower jaw beneath Ahab and bit off his leg" (ZHAO, 1999). "Since then, Ahab wanted revenge against the whale" (ZHAO, 1999). As a great captain on the sea for 40 years, he loses a leg. In 
his opinion, he is insulted by his enemy, then he makes a fake leg with the bone of whale. It seems that this always reminds him of not forgetting the past, as Ishmael says, "What the white whale to Ahab, has been hinted; what, at this, he was to me, as yet remains unsaid. It was the whiteness of the whale that above all things appalled me" (Melville, 2004).

\section{Differences of the Object of Revenge}

Hamlet's object of revenge, from appearance, is only the present king-Claudius, but if goes deeper, it is not difficult to find that the enemy force behind the Claudius, at that time, the king of the country represents all; he has the absolute power, although, Hamlet is the present prince of Denmark, the only legal inherit of throne of Denmark, all the things in the court is arranged by Claudius; all the soldiers should obey Claudius and performance his order. Here, Claudius is "remorseless, treacherous, lecherous, kindles villain" (Shakespeare, 2001). "Ay, that incestuous, that adulterate beast, with witchcraft of his wit, with traitorous gifts, $O$ wicked wit and gifts, that have the power so to seduce" (Shakespeare, 2001). Hamlet is weak, then, they are willing to follow Claudius instead of Hamlet, who has no real power in the court.

An earnest conjuration from the King,

As England was his faithful tributary.

Hamlet is fighting against the whole Claudius force. The enemy before the prince is powerful. Hamlet is no individual revenge tragedy of the character, but something more; "It is the tragedy of society, because the king who kills his brother and marries his sister-in-law" (Ma, 2004), which is violently against the natural law. It cannot be accepted by the society, by the people at that time at that age. If the natural law is broken, the more terrible unwanted sins will come up.

Moby Dick tells the story of Ahab's revenge, with latent them of man's fighting against gods. The hero's combat strength comes from an irrational power in his inner world and his most daring revolt against God, which gives vent to the subject's lust. As the king of the sea, "Moby Dick was also different in behavior from other whales. He seemed to be more clever than the rest" (Melville, 2004). It is not a simple animal; it is the dominant symbol of all. It is the symbol of nature. I assume Moby Dick and whiteness are really two inseparable aspects of one thing; Moby Dick is the personification of whiteness. In Ahab's eyes, Moby Dick is the evil of the sea; it is the Moby Dick that has grabbed one of his legs, and it is also the white whale that has broken his common life; at the same time, whaling is an activity which takes place in actual world, of nature. When the whale is killed by people, the balance and the peace of the nature is broken, and Moby Dick, as a whale, is belonging to the nature, and it is the son and representative of nature; therefore, Ahab is not only fighting against the Moby Dick, but also fighting with the nature.

\section{From Fighting Against Society, Nature, and Achievements, Who Is Great?}

Hamlet's powerful enemy is Claudius force, in the process of fighting against Claudius, Hamlet, as a humanist, has no friend to help him. Claudius is not only the present king of Denmark, but also the representative of present society; it is he who makes the country in disorder. Claudius is cunning and is in the lack of humanity. For all of this, Hamlet, as the prince, the only legal inherit of throne, should take action immediately to kill Claudius for the country people, but he does not, even finally he finds the truth of his father's death by asking a group of actors to stage a play of murder before the new king, who leaves the performance before it is thought, he then decides to kill the culprit, but he just stops as he passes the king's 
chamber and sees him praying, it is a so-called better chance for him to kill the cunning king, he does not take action. Hamlet is fully aware of his own deficiency, he just pretends to be mad; from this, Hamlet has the burden of old thought which curbs his thinking and action. At the same time, he does not seek for help from others. Facing Claudius, Hamlet chooses only himself to fight against the enemy; his failure is destined from the very beginning of the play.

Moby Dick is the representative of nature; it is the son of nature; at the same time, it represents the outer mystery, which is like a magnet, forever and in the end overwhelms the imagination of human beings. What we chiefly confront and observe is the tragedy of Ahab in his revengeful attack upon the great white whale. Ahab swears to dismember the whale as it does to him. The white whale is all evil to Ahab. William Eilery Sedgwick is right when he proclaims that "Nevertheless it is wrong to say, as do almost all the critics of Moby Dick, that Melville intended him to present evil". The white whale has a tremendous power to do harm, while Ahab clearly represents a self-proclaimed sovereign individual who defies human limitations in searching for insight into the mystery of the universe. When we traces the origin of Ahab's hatred, we find the chief root of his hatred lies not in the whale's dismemberment of him but in the fact that he cannot comprehend Moby Dick's existential meaning. Ahab therefore seeks to destroy the whale, thereby eliminating that in the world which he does not understand and by extension cannot control, he wants to control the nature, he wants to control the whale, Bravery sprite is shown on him, when captain Boomer, who has lost an arm to Moby Dick, warns Ahab that "he is best let alone, don't you think so, captain?", Ahab replies, "He is, But he will still be hunted, for all that, what I best let alone, the accursed thing is not always what least allures, He is all a magnet". So Ahab's tragedy lies in his futility in provoking the mystery of nature, which is unfathomable. Ahab hates Moby Dick which is embodiment of nature also because he feels his pride is wounded and his human dignity is challenged. That civilized man is fundamentally different from and superior to uncivilized man and wild beasts. Ahab finds the whale's seeming superiority inscrutable; he finds behind a competing mind, to become himself, he must destroy it, his monomania is that he fears that a mere animal might be more powerful than him, thus he must over compensate for his fear by constantly asserting the ascendancy of his own ego. Ahab always yeans to keep animal and human distinct, while repeatedly discovers that humans and animals overlap, that no fundamental differences exist between them. According to 3 days' chase, Ahab bravely fights against nature and finally he finishes his purpose of killing Moby Dick and avenging himself, During the process, many of deaths are caused.

\section{From Social Morality and Attitude of Treating Others, Who Is Great?}

Hamlet, as a humanist, combats violence and shows merciless to the other people with good attitude. "I pray you all, if you have hitherto conceal'd this sight. Let it be tenable in your silence still; and whatsoever else shall hap to-night. Give it an understanding, but no tongue; I will requite your loves". He has no tone of order to inferiority. During the process of revenge, he kills Claudius by only his own strength. There is also another reason behind this that Hamlet does not hope more people are involved in this battle, because he is unwilling to see more deaths for revenge. When the truth of the murdering exposes to the public, he pretends to be mad before his lover. He does not let it be known by his mother, and his friends. One of the reasons is that Hamlet is for the safety of them. When Claudius arranges a fuel for him, he does not refuse the fuel even he knows that it is conspiracy; at last, Hamlet does not let the chance go away, he seizes the chance to kill Claudius. All of these show the merciless of Hamlet to the others, and this is worth praising. 
From the beginning of the play, killing the whale is only Ahab's own purpose, his own will. Ahab stands for the inscrutable mystery of creation, as he also stands for what man sees in creation of himself, absolute master of his crew, out sight of all civil restrains, opposed by nothing except the magnitude of his task and the craft of his antagonist. Ahab becomes more truly a monster than Moby Dick. He is vengeance in the flesh, a seeker without bounds to his desire; he becomes the image of the thing he hates; he has lost humanity in the very act of vindicating it. As Starbuck warns "Let Ahab aware of thyself old man", and when Stub half-jokingly asks captain Ahab, Ahab shouts to him "Go below deck, you dog" (Shakespeare, 2001). "Then I'll ten times call you a donkey. Be gone, you fool, or I'll clear the world of you" (Shakespeare, 2001). Ahab is so stubborn in overpowering the supernatural creature- - he refuses to consider any human limitations; he insists on employing human power and seeing with his human eyes, he will not accept a mystery that cannot be grasped by his mind. All this leads to Ahab's tragic end. When Ahab declares his real purpose of the voyage, he is swept totally into the magnet of Ahab's mad super naturalistic monomania. Ahab is not friendly to his crew on the Pequod; even he takes only a coin to lure his crew to work hard to seek for the white whale for his own purpose of killing Moby Dick.

\section{Conclusion}

From the angle of character tragedy, similarities and differences of revenge, fighting against society and nature, social morality, and other aspects, this paper analyses the two heroes-hamlet and Ahab. During the process of revenge, Hamlet meets some obstacles; the one is that the king is very cunning and to kill a king who seizes the supreme power is not so easy; the last but the most important one is that Hamlet cannot kill the king privately that will bring on himself the occasion of trying to seize crown by occasion. From this, the failure of Hamlet is doomed, while Ahab organizes the crew of Pequod to work hard for Ahab's personal will and personal purpose, he finally finishes the task of killing the white whale. In the process of fighting against society and nature, as a humanist, his new idea cannot do anything to the powerful feudalism. Facing Claudius, he chooses to fight against Claudius privately; it is in the lack of necessary condition of success. While Ahab is longing for success, what he has done is all for killing Moby Dick. He wants to control the nature; he wants to control the whale. He finds behind competing mind, to become himself, he must destroy it; finally he kills the whale. From social morality and attitude of treating others, Hamlet shows sympathy to the poor people. He avenges not only his father but also his country. In fighting against Claudius, he pretends to be mad and not let others know the fact, because he does not want to involve many other innocent people in the battle, and he does not want to cause innocent death, while chasing and killing Moby dick is only Ahab's personal will. He takes no account for others' life; he is willing to kill Moby dick at any prices. He always says rudely to his crew on Pequod.

According to the above analysis, Hamlet and Ahab are both tragedy heroes. We cannot simply judge a person's greatness according to several aspects; we can also not simply say who is great from several aspects. It is just a comparative saying and standard. From the process of revenge, fighting against society, nature, and achievements, Ahab may be comparatively greater; from social morality and attitude of treating others, maybe Hamlet is greater. 


\section{References}

MA, L. (2004). Why does Hamlet have so many difficulties in revenging his father? Academic Journal of Zhongzhou University, 4, 64-65.

Melville, H. (2004). Moby Dick. (J. J. DUAN \& L. YANG, Trans.). Beijing: Aviation Industry Press.

Shakespeare, W. (2001). Hamlet. (S. Q. LIANG, Trans.). Beijing: China Radio and Television Press.

WANG, X. L. (1997). A comparison and contrast between Hamlet and death of a salesman. Academic Journal of Xi'an International Studies University, 1, 55-57.

ZHAO, P. (1999). The ambiguity of life itself. Academic Journal of Minjiang University, 4, 43-44. 